\title{
Detection of Clostridium difficile toxins A and B in the stool specimens from patients and medical staff of the children's antituberculosis department
}

\author{
O. H. Ivanko, M. V. Patsera, Ya. S. Skrypnykova
}

Zaporizhzhia State Medical University, Ukraine

Key words:

children,

Clostridium

difficile infection

(CDI), rifampicin,

medical staff.

Zaporozhye

medical journa

2018; 20 (5), 692-695

Dol:

10.14739/2310-1210

2018.5.141724

E-mail:

7dr.marina@gmail.com
The objective of our research was to determine the detection frequency of $C$. difficile toxins in the stool specimens from children receiving long-term treatment with rifampicin and in health care workers treating these children in a separate anti-tuberculosis hospital.

Materials and methods. 139 children with the average age of 13.6 were examined; all of them had an infiltrative pulmonary tuberculosis and received long-term treatment with rifampicin at the Zaporizhzhia Regional Tuberculosis Dispensary. Also, 32 medical workers were examined and divided into high and low risk groups of $C$. difficile infection depending on the closeness of their contacts with children at the department. To detect $C$. difficile toxins $A / B$ in the stool an ELI method was applied using the ELISA test system (Diagnostic Automation, Inc., Calabasas, USA). The amount of toxins ranged from $1 \mathrm{ng}$ and more in $1 \mathrm{ml}$ of feces sample was considered as diagnostic.

Results. 74 (53 \%) children out of the 139 had a diagnostic titer of $C$. difficile toxins in their stool specimens. Among them, 49 $(66 \%)$ children had recurrent diarrhea, syndrome of abdominal pain without diarrhea was observed in $20(27 \%)$ and asymptomatic carrier state of $\mathrm{CDI}$ detected by laboratory tests was defined in $5(7 \%)$ children. Among 32 medical workers in the same department $6(18.8 \%)$ of them were positive for $C$. difficile toxins. It is noteworthy that three of them had received antibiotics during the last month prior to the study.

Conclusions. In the context of professional contacts with symptomatic or asymptomatic CDI children there is the risk of intestinal contamination among the health workers who intake antibiotics regardless of contacts closeness and total years of service at the hospital. At the same time, patients without diarrhea and, possibly, health workers of the department can be considered as an additional reservoir of $C$. difficile.
Кнючові слова:

Аіти,

Clostridium difficile

інфекція - CDI,

рифампіцин,

медичні

працівники.

Запорізький

медичний

журнал. - 2018. -

T. 20, № 5(110).

C. 692-695

\section{Виявлення токсинів A + В Clostridium difficile у фекаліях пацієнтів і медичних працівників дитячого протитуберкульозного віддікення}

\section{О. Г. Іванько, М. В. Пацера, Я. С. Скрипникова}

Мета роботи - встановлення частоти виявлення токсинів C. difficile у фекаліях у дітей, які тривалий час отримують антибіотик рифампіцин, а також у фекаліях медичного персоналу, що здійснює догляд за цими дітьми в умовах протитуберкульозного закритого стаціонара.

Матеріали і методи. Обстежили 139 дітей (середній вік - 13,6 року), які страждали на інфільтративну форму легеневого туберкульозу та тривалий час отримували рифампіцін в умовах відділення обласного протитуберкульозного диспансеру м. Запоріжжя. Також обстежили 32 медичних працівників, яких залежно від контактів із дітьми у відділенні поділили на групи високого та низького ризику інфікування C. difficile. Для виявлення токсинів A + B C. difficile у фрекаліях використовували імуноферментний метод за допомогою тест-системи ELISA (Diagnostic Automation, Inc., Calabasas, USA) фотометр TECAN, SUNRISE. Позитивним результатом наявності CDI у хворого вважали кількість токсинів 1 нг і більше в 1 мл фрекалій.

Результати. 3і 139 дітей у 74 (53 \%) наявні токсини C. difficile у фекаліях, що діагностично значущо для CDI. Серед усіх токсин-позитивних дітей 49 (66 \%) були з діареєю, що рецидивує, больовий абдомінальний синдром без діареї визначили у 20 (27\%), безсимптомні носії CDI, виявлені лабораторними тестами, - 5 (7 \%) дітей. Серед 32 медичних працівників цього відділення з різним ступенем контакту з дітьми за результатами тестів на токсини C. difficile позитивними були 6 (18,8 \%) співробітників. Серед них троє отримували антибіотики протягом останнього місяця перед дослідженням. Встановлено, що інтенсивність контактів співробітників із хворими дітьми у відділенні, а також стаж роботи у спеціалізованому протитуберкульозному відділенні не вплинули на частоту інфікування C. difficile.

Висновки. В умовах професійних контактів з дітьми, хворими на CDI маніфестну та безсимптомну форми, ризик розвитку у співробітників контамінації кишечника виникає при прийманні антибіотиків незалежно від контактів медичних працівників і стажу роботи у стаціонарі. Пацієнти без діареї та, можливо, медичні працівники відділення можуть бути додатковим резервуаром C. difficile.

Ключевые слова: Аети, Clostridium difficile infection $\mathrm{CDI}$, рифампицин, медицинские работники.

\section{Выявление токсинов A + B Clostridium difficile в стуле пациентов и медицинских работников детского противотуберкулезного отделения}

\section{О. Г. Иванько, М. В. Пацера, Я. С. Скрипникова}

Цель работы - установление частоты выявления токсинов C. difficile в стуле у детей, длительно получающих антибиотик рифампицин, а также у медицинского персонала, осуществляющего уход за этими детьми в условиях противотуберкулезного закрытого стационара. 
Материалы и методы. Обследовали 139 детей (средний возраст - 13,6 года), которые страдали инфильтративной формой легочного туберкулеза и получали длительно рифампицин в условиях отделения Областного противотуберкулезного диспансера г. Запорожья. Также обследовали 32 медицинских работника, которых в зависимости от тесноты контактов с детьми в отделении разделили на группы повышенного и низкого риска инфицирования C. difficile. Для установления токсинов A + B C. difficile в стуле использовали иммуноферментный метод с помощью тест-системы ELISA (Diagnostic Automation, Inc., Calabasas, USA) фотометр TECAN, SUNRISE. Позитивным результатом наличия CDI у больного считали количество токсинов 1 нг и более в 1 мл фекалий.

Результаты. Из 139 детей у 74 (53 \%) обнаружили токсины C. difficile в стуле, что диагностически значимо для CDI. Cреди всех токсин-позитивных детей 49 (66 \%) были с рецидивирующей диареей, болевой абдоминальный синдром без диареи установлен у 20 (27 \%), бессимптомное носительство CDI, обнаруженное лабораторными тестами, - у 5 (7\%) детей. Среди 32 медицинских работников этого же отделения с разной степенью контакта с детьми положительными по результатам тестов на токсины C. difficile оказались 6 (18,8 \%) сотрудников. Из них трое принимали антибиотики в течение последнего месяца перед исследованием. Установлено, что ни интенсивность контактов сотрудников с больными детьми в отделении, ни стаж их работы в специализированном противотуберкулезном отделении не влияли на частоту инфицирования C. difficile.

Выводы. В условиях профрессиональных контактов с детьми, больными CDI манифестной и бессимптомной формами, риск развития у сотрудников контаминации кишечника возникает при приеме антибиотиков независимо от тесноты контакта медицинских работников и их стажа работы в стационаре. Пациенты без диареи и, возможно, медицинские работники отделения могут быть дополнительным резервуаром C. difficile.

\section{Introduction}

Over the past decade, a significant increase in mortality from an infection caused by Clostridium difficile (C. difficile infection or $\mathrm{CDI}$ ) has been observed in the North American continent and Europe $[1,2]$. The increase in the incidence and severity of CDI, as well as the mortality rate among hospitalized patients in recent years, have made this disease a global health care system problem, which makes it necessary to study the evolution of $C$. difficile and CDI epidemiology [3,4]. The pathomorphosis of CDI could be associated with the spread of the hypervirulent $C$. difficile strain, BI/NAP1/027, resistant to fluoroquinolone [2]. Genetic analysis points to the unstable $C$. difficile genome, which facilitates the adaptation of $C$. difficile to environmental changes and, therefore, leads to the emergence of more virulent strains [5]. A nosocomial model of CDI development as a hospital-acquired infection with diarrhea development, as well as its asymptomatic form, i.e. carriage of $C$. difficile $[6,7]$, have been proposed. One of the reasons for the high degree of $C$. difficile seeding could be the formation of highly resistant and easily transferable spores, which requires new approaches to fighting infection and prevention methods [8]. Patients with manifest forms of $\mathrm{CDI}$ and asymptomatic carriers could equally spread the spores that lead to both direct (a person-to-person contact) and indirect $C$. difficile transmission [9]. In $60 \%$ of cases the healthcare personnel clothing was colonized by pathogenic bacteria, including drug-resistant microorganisms [10]. Asymptomatic carriage of $C$. difficile toxigenic strains, according to Stoesser N., 2017, could begin as early as after birth. Early C. difficile colonization forms protective properties of the intestine and reduces the risk of CDI development in the future [7]. The role of $C$. difficile asymptomatic carriage as an infectious reservoir for the CDI development in patients within the hospital is increasingly recognized. This fact involves the transmission of strains from asymptomatic carriers who have begun antibacterial therapy, as well as from patients who have been in hospital for a long time or who have received pathogenic strains from medical personnel $[11,12]$. The importance of $C$. difficile asymptomatic carriage in intestinal clostridiosis occurrence requires the revision of measures in order to protect and prevent the development of CDI among patients and hospital staff $[13,14]$.

\section{The objective}

The objective of our research was to determine the detection frequency of $C$. difficile toxins $A / B$ in the stool specimens from children receiving long-term antibiotic treatment (necessarily including rifampicin) and simultaneously in medical personnel treating these children in a separate anti-tuberculosis hospital.

\section{Materials and methods}

The observations were conducted in the Children's Department of the Regional Tuberculosis Dispensary in Zaporizhzhia. 139 c0068ildren (68 girls and 71 boys, aged 3 to 17 years) with infiltrative pulmonary tuberculosis (code A15 according to ICD-10) were examined. The average age of patients was $13.6 \pm 4.6$ years. All children received long-term antibiotic therapy according to the Order of the Ministry of Health of Ukraine № 731 dated 16.08.2013, administered therapy based on five categories of TB treatment.

32 healthcare workers were also examined. Depending on their contacts closeness with children in the department, healthcare workers were divided into the following groups. The high risk group of $C$. difficile infection included 20 nurses and hospital orderlies. The second group with a relatively low risk of infection included 12 healthcare workers: doctors, tutor, procedural nurses and a housekeeping nurse. To determine the $C$. difficile enteropathogenic toxin $A$ and necrotic toxin $B$ in the stool an enzyme immunoassay with the ELISA test system (developed by Diagnostic Automation, Inc., Calabasas, USA), Sunrise photometer (TECAN) were used. According to the manufacturer, the sensitivity and specificity of this ELISA test system were $94 \%$ and $100 \%$, respectively. The measurement range was from 0 to $10 \mathrm{ng}$ of toxins per $1 \mathrm{ml}$ of feces. The amount of toxins ranged from $1 \mathrm{ng}$ and more in $1 \mathrm{ml}$ of feces sample was considered as a positive result of $\mathrm{CDI}$ occurrence in the patient.

The results of the observations were processed using the methods of medical statistics by the certified program Statistica v.6.1. (license software package AXXR712D83321FAN5).
Запорожский медицинский журнал. - 2018. T. 20, № 5(110). C. 692-695 


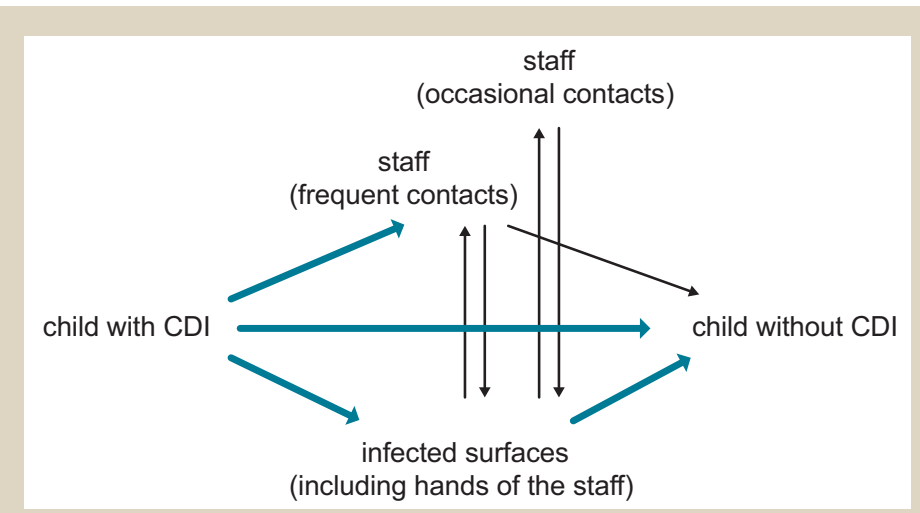

Fig. 1. Highly significant (bold lines) and less significant (thin lines) transmission routes of $C$. difficile among patients and medical staff in a pediatric hospital.

\section{Results and discussion}

The data of our study showed that $C$. difficile toxins had been isolated in 74 (53\%) of the 139 stool specimens of children treated in the separate specialized department, which is diagnostic for CDI. The clinical course of intestinal infectious disease was different. Among the all children with toxigenic $C$. difficile the most had recurrent diarrhea (49 or $66 \%$ ); abdominal pain syndrome without diarrhea was observed in 20 (27\%) and asymptomatic carriage of CDI, detected by laboratory tests, was found in $5(7 \%)$ children. Symptoms of $C$. difficile infection such as abdominal pain, bloating, nausea, glossitis and stomach rumbling and fullness could have occurred even after 2 months of antibiotics treatment. Children suffered particularly from taking several anti-tuberculosis medications. Undulating course of CDI was also observed during a prolonged (up to 12 months) therapy.

The development of CDI in the examined children, in our opinion, was based on two events: the intestinal microbiota alteration (due to the prolonged intake of aggressive antibiotics) and $C$. difficile spores ingress through the fecal-oral route, which is traditional for the onset of intestinal infections. The risk factors for CDI development in children were long-term antibiotic therapy, the age of some patients younger than 5 years and long-term inpatient treatment in a separate hospital.

Since the potential risks of medical personnel contamination in a separate specialized children's department following contact with a large number of $C$. difficile toxins-positive children are insufficiently covered in the literature, we decided to find out the transmission chains in the occurrence of CDI.

We examined 32 health care workers of the same department. All of them were divided into three groups based on the degree of their contact with the children. The 1st group included those who communicated with children most closely, i.e. nannies and nurses. The staff included in the 2nd group, the procedural nurses, had less close communication with children, while tutors, kitchen staff and doctors included in the 3rd group had even less frequent contacts with children. Among health care workers, 6 (18.8\%) were C. difficile toxins-positive. It should be noted that three of them received antibiotics during the last month before the study. It has been found that the intensity of contacts with sick children in the department does not affect the incidence of $C$. difficile infection, since in all groups, both those who had frequent contacts with patients and those who did not have frequent contacts, the number of infected persons did not differ statistically $\left(X^{2}=1.2, d f=1, P>0.1\right)$. The seniority of medical personnel in the specialized tuberculosis department ranged from 3 to 14 years and also did not affect the frequency of $\mathrm{CDI}$ detection in health care workers.

It has been suggested that the source of infection could be hands, furniture and medical equipment as well as healthcare workers' clothing. Their surfaces were contaminated with $C$. difficile spores and virulent microorganisms transmitted by both patients and medical personnel. Environmental shedding of $C$. difficile is possible by both infected individuals with diarrhea and asymptomatic carriers. The latter's role is particularly important in the definition of reservoirs and carriers. The question of whether these bacteria could cause infection in patients requires further research. Obviously, the transmission routes of $C$. difficile are different. The figure below shows the expected transmission routes of $C$. difficile among patients and medical personnel in a pediatric hospital.

However, infection control measures should focus on two goals: reducing patients' susceptibility to CDI through rationalization of antibiotic therapy and preventing the transmission of microorganisms among patients and medical personnel. In the hospital, detergents containing ammonium salts were used for disinfection of surfaces, which did not prevent the sporulation in Clostridium. The medical personnel used an ethanol-based hand gel for sanitization, which was not effective for the elimination of $C$. difficile. $10 \%$ sodium hypochlorite, suitable for $C$. difficile environmental stress, was not used in the hospital. The use of gloves during contacts with patients without diarrhea was rare and did not take into account the risk of contact with carriers of virulent C. difficile strains in patients with asymptomatic forms of $\mathrm{CDI}$. It has been noted that frequent and thorough hand washing with chlorhexidine or water with soap was effective for the mechanical removal of $C$. difficile spores from the skin of the hands. It is the hygiene and medical skills set of health care workers which are more important than the isolation of infected patients in single rooms.

\section{Conclusions}

1. The rate of children receiving treatment for pulmonary tuberculosis at the Zaporizhzhia Regional Tuberculosis Dispensary who had C. difficile toxins in their stool is $53 \%$.

2. The rate of medical workers in the department with positive tests for $A / B C$. difficile toxins in their stool is $18.8 \%$. The fecal excretion of enteropathogenic and necrotic toxins was not accompanied by clinical symptoms of CDI.

3. In the context of professional contacts with symptomatic or asymptomatic CDI children the risk of intestinal contamination development among the health workers increases with antibiotics intake, regardless of contacts closeness and total years of service at the hospital.

4. Patients with manifest CDI are the most important source of $C$. difficile infection for patients and medical personnel at a pediatric hospital. At the same time, patients without diarrhea and, possibly, medical workers of the department can be considered as an additional reservoir of $C$. difficile. 
Prospects for further research. The search for effective CDI prevention measures among patients and medical personnel in separate tuberculosis treatment facilities should be performed using effective decontamination methods of utensils, furniture surfaces and medical equipment, as well as isolation of patients with CDI from healthy individuals.

Conflicts of Interest: authors have no conflict of interest to declare. Конфлікт інтересів: віАсутній.

\section{Information about authors:}

Ivanko O. H., MD, PhD, DSc, Professor, Head of the Department of Propaedeutics of Children's Diseases, Zaporizhzhia State Medical University, Ukraine.

Patsera M. V., MD, PhD, Associate Professor, Department of Propaedeutics of Children's Diseases, Zaporizhzhia State Medical University, Ukraine.

Skrypnykova Ya. S., MD, Assistant, Department of Propaedeutics of Children's Diseases, Zaporizhzhia State Medical University, Ukraine.

\section{Відомості про авторів:}

Іванько О. Г., А-р меА. наук, професор, зав. каф. пропедевтики Аитячих хвороб, Запорізький Аержавний меАичний університет, Україна.

Пацера М. В., канА. меА. наук, доцент каф. пропедевтики Аитячих хвороб, Запорізький Аержавний медичний університет, Україна.

Скрипникова Я. С., асистент каф. пропедевтики дитячих хвороб, Запорізький Аержавний медичний університет, Україна.

\section{Сведения об авторах:}

Иванько О. Г., А-р меА. наук, профессор, зав. каф. пропедевтики Аетских болезней, Запорожский государственный меАицинский университет, Украина.

Пацера М. В., канА. меА. наук, доцент каф. пропедевтики Аетских болезней, Запорожский государственный медицинский университет, Украина.

Скрипникова Я. С., ассистент каф. пропедевтики Аетских болезней, Запорожский государственный медицинский университет, Украина.

Надійшка Ао редакції / Received: 02.05.2018

Після Аоопрацювання / Revised: 21.05.2018

Прийнято Ао Аруку / Accepted: 31.05.2018

\section{References}

[1] Lessa, F. C., Mu, Y., Bamberg, W. M., Beldavs, Z. G., Dumyati, G. K., Dunn, J. R., Farley, M. M., et al. (2015). Burden of Clostridium difficile infection in the United States. N Engl J Med, 372(9), 825-834. doi: 10.1056/NEJMoa1408913.

[2] Van Dorp, S. M., Notermans, D. W., Alblas, J., Gastmeier, P., Mentula, S., Nagy, E., et al. (2016). Surveillance and outbreak report Survey of diagnostic and typing capacity for Clostridium difficile infection in Europe, 2011 and 2014. Euro Surveillance journal, 21(29). doi:10.2807/1560-7917. ES.2016.21.29.30292.

[3] Balsells, E., Filipescu, T., Kyaw, M. H., Wiuff, C., Campbell, H., \& Nair, H. (2016). Infection prevention and control of Clostridium difficile: a global review of guidelines, strategies, and recommendations. J Glob Health, 6(2), 020410. doi: 10.7189/jogh.06.020410.

[4] Domeniconi, G., Serafino, S., Migone, De Amicis., M., Formica., S., Lanzoni, M., et al. (2016). Clostridium difficile infection epidemiology and management: Comparison of results of a prospective study with a retrospective one in a reference teaching and research hospital in Northern Italy. Am J Infect Control, 44(11), 1214-1218. doi: 10.1016/j. ajic.2016.05.003.

[5] Kumar, N., Miyajima, F., He, M., Roberts, P., Swale, A., Ellison, L., et al. (2016). Genome-Based Infection Tracking Reveals Dynamics of Clostridium difficile Transmission and Disease Recurrence. Clin Infect Dis, 62(6), 746-752, doi: 10.1093/cid/civ1031.
[6] Tabak, Y.P., Johannes, R. S. Sun X Nunez C. M \& McDonald, L. C. (2015). Predicting the risk for hospital-onset Clostridium difficile infection (HO-CDI) at the time of inpatient admission: $\mathrm{HO}-\mathrm{CDI}$ risk score. Infect Control Hosp Epidemiol, 36(6), 695-701. doi: 10.1017/ice.2015.37.

[7] Stoesser, N., Eyre, D. W., Quan, T. P., Godwin, H., Pill, G., Mbuvi, E., et al. (2017). Epidemiology of Clostridium difficile in infants in Oxfordshire, UK: Risk factors for colonization and carriage, and genetic overlap with regional C. difficile infection strains. PLoS One, 12(8). doi: 10.1371/ journal.pone.0182307.

[8] Peng, Z., Jin, D., Kim, H. B., Stratton, C. W., Wu, B., Tang, Y. W., \& Sun, X. (2017). Update on Antimicrobial Resistance in Clostridium difficile: Resistance Mechanisms and Antimicrobial Susceptibility Testing. J Clin Microbiol, 55(7), 1998-2008. doi: 10.1128/JCM.02250-16.

[9] Haun, N., Hooper-Lane, C., \& Safdar, N. (2016). Healthcare Personnel Attire and Devices as Fomites: A Systematic Review Infect Control Hosp Epidemiol, 37(11), 1367-1373. doi:10.1017/ice.2016.192.

[10] Furuya-Kanamori, L., Clements, A. C. A., Foster, N. F., Huber, C. A. Hong, S., Harris-Brown, T., et al. (2017). Asymptomatic Clostridium difficile colonization in two Australian tertiary hospitals, 2012-2014 prospective, repeated cross-sectional study. Clin Microbiol Infect, 23(1), 48.e1-48.e7. doi: 10.1016/j.cmi.2016.08.030

[11] Zacharioudakis, I. M., Zervou, F. N., Pliakos, E. E., Ziakas, P. D., \& Mylonakis, E. (2015). Colonization with toxinogenic C. difficile upon hospital admission, and risk of infection: a systematic review and meta-analysis. Am J Gastroenterol, 110, 381-390.

[12] Alasmari, F., Seiler, S. M., Hink, T., Burnham, C. A. \& Dubberke, E. R. (2014). Prevalence and risk factors for asymptomatic Clostridium difficile carriage. Clin Infect Dis, 59(2), 216-222. doi: 10.1093/cid/ciu258.

[13] Dubberke, E. R., Carling, P., Carrico, R., Donskey, C. J., Loo, V. G. McDonald, L. C., et al. (2014) Strategies to prevent Clostridium difficile infections in acute care hospitals: 2014 Update. Infect Control Hosp Epidemiol, 35(6), 628-645. doi: 10.1086/676023.

[14] Napolitano, L. M., \& Edmiston, Jr., C. E. (2017). Clostridium difficile disease: Diagnosis, pathogenesis, and treatment update. Surgery, 162(2), 325-348. doi: 10.1016/j.surg.2017.01.018. 